Swarthmore College

Works

Spring 1979

\title{
Transnational Corporations And The Political Economy Of Export Promotion: The Case Of The Mexican Automobile Industry
}

D. C. Bennett

Kenneth Evan Sharpe

Swarthmore College, ksharpe1@swarthmore.edu

Follow this and additional works at: https://works.swarthmore.edu/fac-poli-sci

Part of the Political Science Commons

Let us know how access to these works benefits you

\section{Recommended Citation}

D. C. Bennett and Kenneth Evan Sharpe. (1979). "Transnational Corporations And The Political Economy Of Export Promotion: The Case Of The Mexican Automobile Industry". International Organization. Volume 33, Issue 2. 177-201.

https://works.swarthmore.edu/fac-poli-sci/71

This work is brought to you for free by Swarthmore College Libraries' Works. It has been accepted for inclusion in Political Science Faculty Works by an authorized administrator of Works. For more information, please contact myworks@swarthmore.edu. 


\title{
Transnational corporations and the
}

\section{political economy of export promotion: the case of the Mexican} automobile industry

\author{
Douglas Bennett and Kenneth E. Sharpe
}

\section{Introduction}

Two World Wars, a depression, and chronic balance of payments deficits impelled most of Latin America to adopt an import substitution strategy towards industrialization well before it became development orthodoxy. A mere two decades after Rául Prebisch's classic statement of the case for import substitution, ${ }^{1}$ however, comparative advantage-based export-oriented strategies were once again coming into vogue, with the new wrinkle that manufactured exports rather than primary product exports were being encouraged. ${ }^{2}$

The new "outward-looking" export orthodoxy details a full bill of particulars against import substitution. Such an industrialization strategy, it is argued, tends to exhaust itself as the "easy opportunities" of domestic

Funding from the following foundations made possible the larger research project of which this paper is a part: The Tinker Foundation, the Social Science Research Council, the Carnegie Endowment for International Peace, and the Doherty Foundation. We are particularly indebted to Linda Lim for comments and criticism on an earlier draft.

${ }^{1}$ Raúl Prebisch, The Economic Development of Latin America and Its Principal Problems (New York: United Nations, 1950).

${ }^{2}$ The most thorough general statement in the argument is in Ian Little, Tibor Scitovsky, and Maurice Scott, Industry and Trade in Some Developing Countries; A Comparative Study (London: Oxford University Press, 1970). See also, Bela Balassa, "Growth Strategies in Semi-Industrial Countries," Quarterly Journal of Economics 84 (1970): 24-42; and Daniel M. Schydlowsky, "Latin American Trade Policies in the 1970s: A Prospective Appraisal," Quarterly Journal of Economics 86 (1972): 263-289.

International Organization 33,2, Spring 1979

0020-8183/79/0002-0177 $\$ 01.00 / 0$

(C) by the Board of Regents of the University of Wisconsin System 
manufacture are used up. ${ }^{3}$ Through high tariffs, a captive market, and an over-valued exchange rate, import-substitution tends to nurture an inefficient manufacturing sector, particularly when and insofar as industrialization is pushed beyond the easy opportunities. Far from curing balance of payments problems, the indictment continues, the inward-looking import substitution strategy has only succeeded in changing the composition of the import bill from consumer to producer goods. And because this shift has made imports more difficult to curtail in the short run without risking a serious recession, it is argued that import substitution has tended to strengthen the links of dependency. ${ }^{4}$

To be sure, many of the arguments that have been lodged against import substitution policy pertain not to the policy as such but rather to the manner in which it has been carried out. Import substitution need not, as Bela Balassa seems to contend, ignore "the economic cost of policy alternatives," apply protective measures "haphazardly," "neglect . . . the interrelationships of individual industries," nor retain protective measures in an industry "ad infinitum," well beyond its infant industry stage. ${ }^{5}$ In truth, the boosting of export promotion as an alternative development strategy has to some extent relied on an unfair comparison of import substitution as it has been carried out, full of the imperfections and irrationalities of actual policy, with an idealized depiction of export promotion as it might be pursued.

The burden of this article will be to anticipate problems with the export promotion strategy in sectors dominated by transnational corporations, problems that are not evident in the idealized portrait of export promotion that has been drawn by neo-classical economics, a portrait that exhibits considerable abstraction from real world governments, buyers, sellers, and markets. The case for export promotion often supposes that the exports that are to be developed are ones from labor-intensive sectors, which are less often dominated by TNCs. Planners in developing countries, however, frequently look to promote exports from the high-technology, capital-intensive sectors in which TNCs predominate, precisely because of the export capability that such corporations are held to possess. The presence of TNCs in a manufacturing sector may seriously alter the possibilities and conditions of success of an export promotion strategy, however. In the discussion that follows, specific reference will be made to the case of the automobile industry in Mexico.

Briefly stated, the argument on behalf of the export promotion strategy contends that manufactured exports are necessary to permit continued economic growth (the opportunities of import substitution having been exhausted), to make use of excess manufacturing capacity (that has inef-

\footnotetext{
${ }^{3}$ For a spirited rebuttal of the exhaustion argument, see Albert O. Hirschman, "The Political Economy of Import-Substituting Industrialization in Latin America," Quarterly Journal of Economics 82 (1968): 1-32.

${ }^{4}$ Daniel Schydlowsky, loc. cit.: 270-271.

${ }^{5}$ Bela Balassa, loc. cit.: 28-37.
} 
ficiently been brought into existence by import substitution), to create jobs, and to cure problems with the balance of payments. The overvalued exchange rates and artificially high input prices that accompany import substitution strategies discourage such manufactured exports, however, and so the policy recommendation that follows from this analysis counsels the dismantling of protective machinery, an end to over-valued exchange rates, and tax subsidies and other measures to induce exports where a comparative advantage may be expected.

The literature that has urged this strategy of export promotion (or "export substitution"' since it seeks to substitute manufactured exports for more traditional primary product exports) has certain recurrent blindspots.

1) Lack of attention to ownership and structural characteristics of specific sectors. Much of the argument for export promotion has been concerned with the orientation of the whole economy (import substitution vs. export promotion) and with the policy tools that serve to set that orientationexchange rate, tariff structure, and tax policy. The presumption, of course, is that manufactured exports will be promoted only in certain sectors. But which sectors? Here the discussion has tended to be concerned only with relative factor prices, overlooking ownership and structural characteristics of specific industries, both domestically and internationally, factors that may be of equal importance in promoting exports. ${ }^{6}$ In order to hold out some hope for genuine economic growth, export promotion arguments must attend to dynamic, not static comparative advantage-to those sectors in which a comparative advantage may be developed. The development of such a comparative advantage requires more than just a facilitative government policy; it requires an entrepreneurial agent. Whether subsidiaries of TNCs can be counted on to play such an entrepreneurial role will depend on structural characteristics of the industry and on organizational characteristics of the transnational firms.

2) Inattention to the demand for manufactured exports. In being predominantly concerned with relative factor prices in particular sectors, attention has been devoted almost exclusively to considerations of supply, particularly to competitiveness in price but also to competitiveness in quality. Surely these are important considerations; but, at best, price and quality-competitiveness are necessary and not sufficient conditions for manufactured exports. It is not sufficient to say as Schydlowsky does, that "commercial channels must be activated;" some attention must be paid to the conditions under which there will be a demand for manufactured exports from developing countries. He notes that the exchange rate structure of many Latin

\footnotetext{
${ }^{6}$ For discussions of the Mexican case that focus exclusively on relative factor prices, see Saúl Trejo Reyes, "El Sector Externo en la Economía Mexicana: Crecimiento Optimo y Política de Exportaciones," El Trimestre Economico, 166 (1975): 399-427; and Robert W. Boatler, "Trade Theory Predictions and the Growth of Mexico's Manufactured Exports," Economic Development and Cultural Change 23 (1974-75): 491-506.

${ }^{7}$ Schydlowsky, loc. cit.: 279.
} 
American countries, in biasing against manufactured exports, tends to create an "inefficiency illusion" of Latin American industry. ${ }^{8}$ But demand will not follow simply and automatically on devaluation, tariff reform, and a public relations effort to dispel the illusion.

Particularly important will be the role that the transnational firms play in the success of export promotion: they "accounted for almost two-thirds of the increase in exports of manufactured goods from Latin America in the decade between 1957 and 1966,"9 and their importance has surely not waned in the decade since. Transnational corporations may pose obstacles as well as provide access to export markets. It is not the legal restrictions that a parent may place on its subsidiaries' exports that are the major concern here (which in any event are increasingly less in evidence as a result of prohibitive legislation in the host countries), but rather the trade consequences of the transnational firm's global strategy. The role of intracompany transfers in hindering or developing manufactured exports may, for example, be an important consideration. More thus needs to be known about the economic circumstances and the government policies under which TNCs will export from developing countries.

3) Inattention to problems of dependency. The export-promotion oriented critique of import substitution strategies notes the strengthening of bonds of dependency as import substitution shifts the composition of imports toward producer goods but is strangely silent on the consequences for dependency of an export promotion strategy. Since such a strategy means a generally greater integration into the world capitalist economy, and often an increased role for transnational corporations, there are dependence considerations that warrant exploration here. This raises another potential problem.

4) Inattention to the problems of implementation and enforcement. It is the rare economist who considers the political preconditions for shifting development strategies or the support and the sanctions necessary to continue implementing them. ${ }^{10}$ Again transnational corporations raise troubling concerns. If these foreign firms originally came to the host country because of its import substitution program, might the government not find it difficult to induce the TNCs to behave in accord with an export-promotion strategy because of these firms' global strategies? If the government comes to depend on transnational corporations for its export-promotion strategy, to what degree will they gain control over the future direction of government policy.

5) Lack of attention to distributional effects of policy. The dominant question in evaluating economic policy alternatives has usually been the question of aggregate growth, although at times it is challenged for centrality by the problem of the balance of payments. What have not been much in

${ }^{8}$ Ibid.: 275-276.

9 Jose de la Torre, "Foreign Investment and Export Dependency," Economic Development and Cultural Change 23 (1974-75): 137-138.

${ }^{10}$ For a distinguished exception, see Albert O. Hirschman, loc. cit. 
consideration are distributional matters: who will share in this growth, and who will benefit from these exports? These questions warrant more attention. ${ }^{11}$

In short, in being the preserve of economists, the export promotion argument has been inattentive to institutions, to distributional questions, and to political factors. A political economy perspective can cure these defects.

In order to give careful attention to institutional and structural considerations this paper focuses on one sector, the automobile industry in Mexico. It is a particularly interesting sector in which to study the potential strengths and weaknesses of shifting from an import substitution to an export promotion strategy. From having been (in the early 1960s) a key sector in government efforts at import substitution, the automobile sector has now come to be seen as an overprotected and inefficient industry, one that uses large amounts of foreign exchange but that could instead be a net generator of foreign exchange. Since 1969 the government has implemented a number of policies principally designed to induce automotive exports. While it may seem that the automobile industry is an unlikely one in which Mexico could have a comparative advantage, Robert Boatler has taken pains to demonstrate that "the indication from Mexico's export experience to date is that the greatest marginal comparative advantage of semi-industrialized countries will be found in the most completely modernized and generally capital-intensive industries." 12 The sort of policy that has been adopted is one that has allowed the firms considerable latitude with regard to the kinds of automobile products that are to be exported. Since automobile products (particularly auto parts) show considerable variation in terms of scale economies, capital intensity, etc., surely each firm could find some automotive products which could be profitably exported. Also, it should be noted, Brazil-a country with roughly similar characteristics-has shown a measure of success in developing automotive exports.

The automobile industry in Mexico is an industry in which there is strong participation of transnational corporations but in which domestic private and state firms play a role as well. In Mexico, the automobile industry has been made something of a paradigmatic case; close attention to this sector should indicate considerations that will be important in other sectors and in other countries.

\section{The Mexican automobile industry}

Since the Second World War, the automobile industry in each of the major manufacturing countries has undergone a substantial process of con-

${ }^{11}$ For one discussion of the merits of import substitution and export promotion on distributional grounds, see Rene Villarreal, El Desequilibrio Externo en la Industrialización de Mexico (1929-1975); Un Enfoque Estructuralista (Mexico: Fondo de Cultura Economica, 1976), pp. 90-103.

${ }^{12}$ Robert Boatler, loc. cit.: 506. 
centration, and this has been both cause and consequence of a marked internationalization of competition with the surviving firms-eight firms accounted for 85 percent of world auto sales in 1973-invading each other's markets. ${ }^{13}$ Increasingly since the mid-1950s, competition in the industry has been characterized by product differentiation, the provision of a wide range of vehicles by each firm, and annual model changes. Because of high scale economies in some phases of production (particularly exterior body stampings) and high fixed-capital costs, the firms have sought to expand the production volumes of their home country plants while contesting for new, developing markets. The larger Latin American countries (Brazil, Mexico, Argentina) have been particularly intense sites of competition. The transnational auto companies supplied these markets first through imports and later (scale economies being markedly lower in this phase) through local assembly of imported kits. In view of the technical and structural characteristics of the industry, it would not have been rational for the firms to move of their own accord to local manufacture, but as a number of these countries, in pursuit of import substitution industrialization strategies, have introduced requirements of minimum local content, the firms have initiated local manufacture rather than surrender the market to competitors. ${ }^{14}$

An additional consideration that bears on the strategies of the automobile firms in locating production facilities concerns the large number of automobile parts that are manufactured by independent suppliers-a pattern that developed to handle special technical problems with some parts and to spread the substantial risk in automobile manufacture. ${ }^{15}$ Because the design of new models requires close coordination with their parts suppliers, the automobile manufacturers have developed intimate relationships with the parts suppliers. They have encouraged the parts suppliers to open foreign subsidiaries in countries where local content requirements have been implemented, but this has not always been possible.

Prior to 1962 the Mexican automobile industry was composed of about a dozen firms assembling automobiles from CKD (completely knocked down) kits and another twenty importing already-assembled vehicles. Three of the assemblers-Ford, G.M. and Fábricas AutoMex (producing Chrysler automobiles)-accounted for nearly three-quarters of the total. The López Mateos government, guided by an import substitution orientation and con-

\footnotetext{
${ }^{13}$ In 1973 the two leading companies, GM and Ford, accounted for over 40 percent of total world automobile sales, and the largest eight for about 85 percent. The largest eight, in order, were GM, Ford, Chrysler, Fiat, Volkswagen, Toyota, Nissan, and Renault. "New Strategies for a World Auto Market," Business Week 24 November 1973: 38. Six of these firms operate in Mexico with wholly foreign-owned subsidiaries (GM, Ford, Chrysler, Volkswagen, and Nissan) or with licensees (DINA-Renault); and only one Mexican firm is affiliated with a transnational firm not among these eight (VAMSA, a minority-owned subsidiary of American Motors).

${ }^{14}$ Rhys Owen Jenkins, Dependent Industrialization in Latin America; The Automotive Industry in Argentina, Chile and Mexico (New York: Praeger Publishers, 1977), p. $20 \mathrm{ff}$.

${ }^{15}$ On the role of risk in creating this pattern, see Lawrence J. White, The Automobile Industry Since 1945 (Cambridge: Harvard University Press, 1971).
} 
Table 1: Composition of the Mexican automotive industry

\begin{tabular}{|c|c|c|c|c|}
\hline \multirow[b]{2}{*}{ Firm } & \multicolumn{2}{|c|}{$\begin{array}{l}\text { Ownership } \\
\text { by Percent }\end{array}$} & \multicolumn{2}{|c|}{$\begin{array}{c}1975 \text { Market Share* } \\
\text { by Percent }\end{array}$} \\
\hline & Foreign & $\overline{\text { Domestic }}$ & Cars & Trucks \\
\hline Chrysler de Mexico, S.A. & 99.1 & 0.9 & 14.3 & 27.1 \\
\hline Diesel Nacional S.A. ${ }^{1}$ & 0 & $\begin{array}{c}100 \\
\text { (Mexican State) }\end{array}$ & 8.1 & 12.4 \\
\hline Ford Motor Co. S.A. & 100 & 0 & 14.5 & 20.2 \\
\hline General Motors de Mexico S.A. & 100 & 0 & 7.9 & 17.2 \\
\hline Nissan Mexicana & 100 & 0 & 10.7 & 5.9 \\
\hline $\begin{array}{l}\text { Vehiculos Automotores } \\
\text { Mexicana S.A. }\end{array}$ & 40 & $\begin{array}{c}60 \\
\text { (Mexican State) }\end{array}$ & 9.3 & 1.7 \\
\hline Volkswagen de Mexico & 100 & 0 & 35.1 & 14.2 \\
\hline
\end{tabular}

${ }^{1}$ Manufactures Renault automobiles under a license.

${ }^{2}$ Manufactures American Motors vehicles.

* Source: Business Trends, 1975, p. 205.

cerned to take measures that would stimulate industrialization and create employment, decreed in 1962 that within two years automobiles sold in Mexico would have to embody at least 60 percent local content including at least the motor and the power train. It decreed further that the firms could manufacture their own motors, but other parts to be counted for local content would have to be procured from independent domestic suppliers. As an important manufacturing sector, the automobile industry was born with this decree. ${ }^{16}$

Eighteen firms made applications to be allowed to manufacture under the terms of the new regimen, and eventually ten of these were approved. Seven still continue to operate. ${ }^{17}$ (See Table 1.) Between 1962 and 1964 the successful applicants made the investments necessary to commence manufacturing operations. In large measure, the burden of creating a parts supply industry fell on these firms in the "terminal industry" (the firms actually producing finished automobiles), most of which were subsidiaries of transnational corporations.

A requirement of 60 percent local content meant that 40 percent of each automobile continued to be imported. As its sales volume grew steadily (see

16 "Decreto que prohibe la importación de motores para automóviles y camiones, así como de conjuntos mecánicos armados para su uso o ensamble, a partir del 10. de septiembre de 1964," Diario Oficial (25 August 1962). For a detailed account of how this decree came about, see Douglas Bennett and Kenneth Sharpe, "Agenda Setting and Bargaining Power in TWC-Host Government Conflicts: The Case of the Mexican Automobile Industry, Comparative Politics, forthcoming.

${ }^{17}$ The three firms that disappeared were Representaciones Delta, which planned to manufacture DKWs and perhaps Mercedes; Reo, which planned to produce Toyotas; and Fabrica Nacional de Automoviles (FANASA) which sold only 2000-3000 Borgwards before closing in 1970. Neither Representaciones Delta nor Reo produced any vehicles under the terms of the 1962 Decree. 


\section{Figure 1: Increasing production of cars and trucks in Mexico}

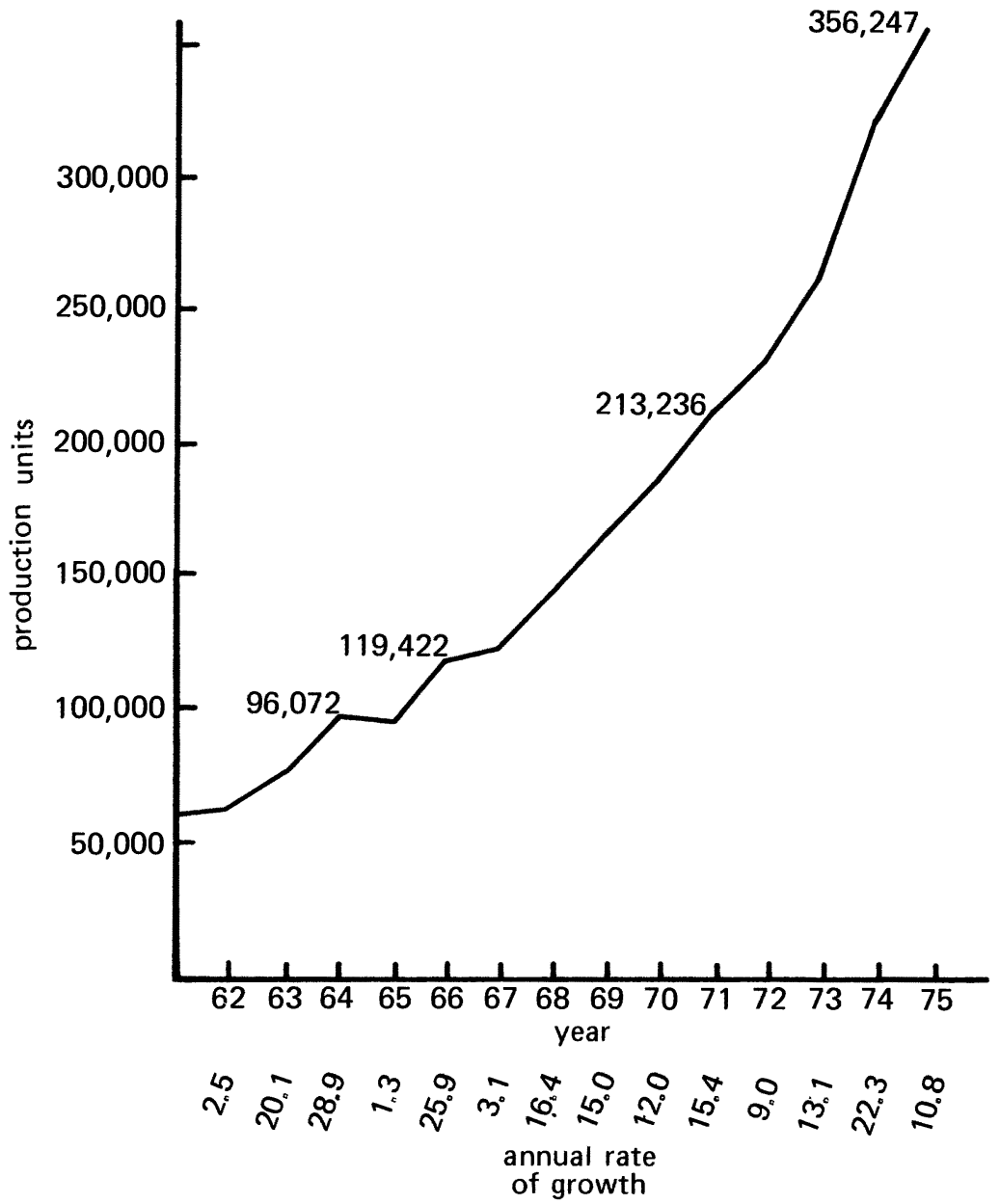

Source: Secretary of Industry and Commerce

Figure 1) through the 1960s, the industry's net balance of payments deficit grew steadily, thus contributing to an increasingly worrisome general balance of payments position (see Figure 2). By the late 1960s, the balance of payments problem had set the basic terms of choice in this sector; government policy makers have struggled with it ever since. Increasing the local content in each vehicle or developing exports to compensate for imports were seen as the two alternative solutions. Both solutions would serve to further spur industrialization. But the choice in this leading sector involved two wider 
Figure 2: The automobile industry's balance of payments by years

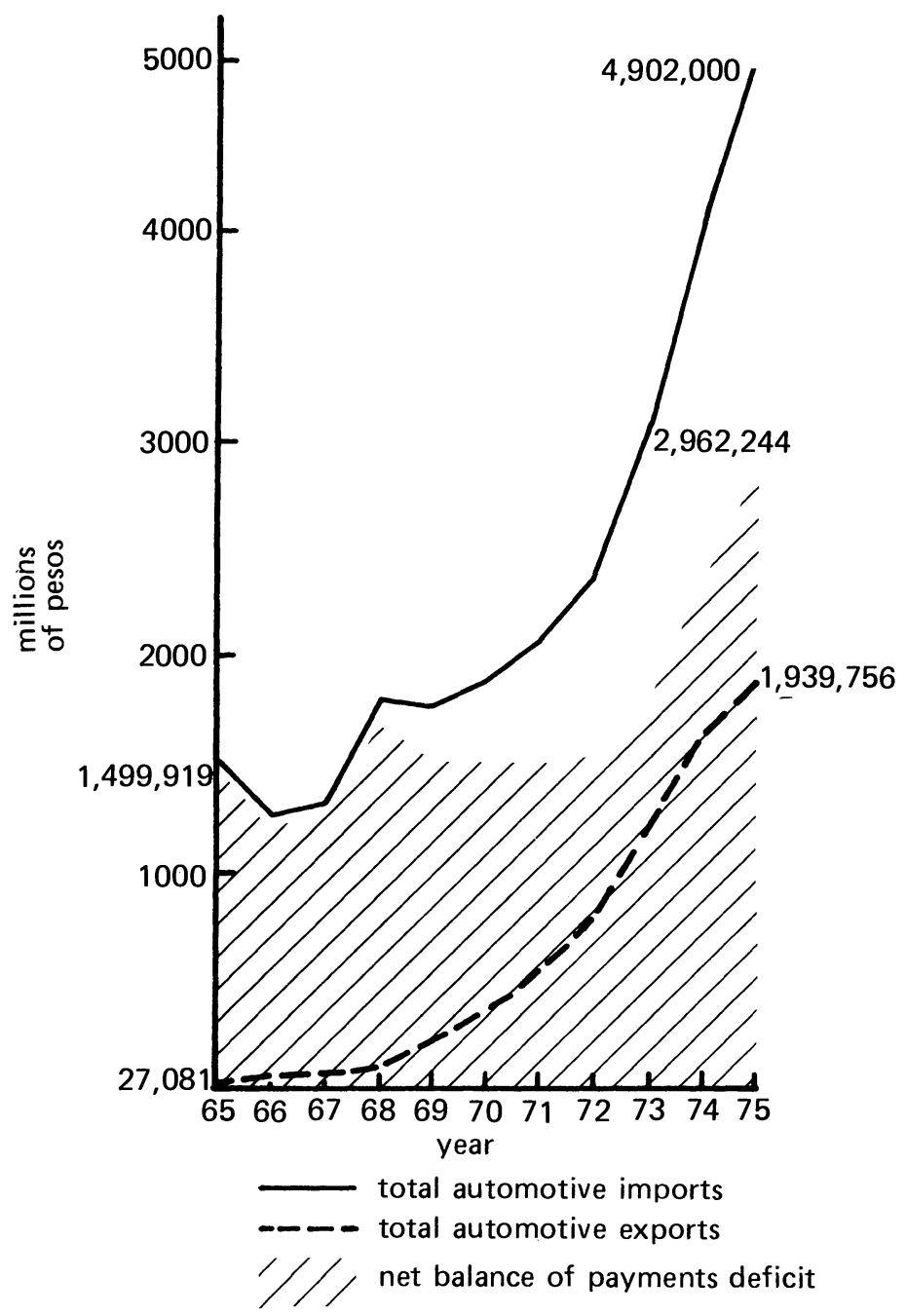

Source: Secretary of Industry and Commerce

alternative growth strategies. If increased local content were adopted as the solution, the long-standing commitment to an import substitution route to industrialization would remain in force; if compensatory exports were adopted, a change of direction, at least a flirtation with a more outward looking, export-promoting strategy would be implied.

The first response of government policy makers was to move toward export promotion. In 1969, the Diaz Ordaz government (1964-1970) required the terminal firms to compensate a steadily increasing percentage of their 
imports with exports; this policy was solidified and extended by the Echeverría regime (1970-76) in 1972. ${ }^{18}$ Non-compliance with export requirements, however, led to problems. In 1976, the Echeverría government drafted a plan oriented toward higher local content rather than exports, but the policy was never promulgated. When the Lopez Portillo government took office in December 1976 it moved toward a compromise position: in its 1977 Decree, it again required the terminal firms to compensate imports with exports, but required a somewhat higher level of local content as well. ${ }^{19}$ What was the rationale behind these government responses? What were the arguments made for the switch from import substitution to export promotion, and what problems led to a re-evaluation of policy?

For reasons that square with the export-promotion critique of import substitution, a choice for more local content faced a number of objections. It was argued that the automobile industry was already producing in Mexico those parts that could be manufactured at costs close to those in more industrialized countries. If more local content were required, the parts that would now have to be domestically manufactured would be parts that could be manufactured only at relatively much higher costs. ${ }^{20}$ An already inefficient industry would be made more inefficient. It was also questioned whether more local content would genuinely help the balance of payments situation, since the additional parts that would now be domestically manufactured would be ones requiring relatively high investments, ${ }^{21}$ much of the machinery and technical assistance having to be obtained outside Mexico. Finally, it was argued that increased local content would cut demand by raising prices, and thus undercut the basic project of industrialization. The cases of Brazil and Argentina, where government policy required nearly 100 percent local content, and where automobile prices were substantially higher, were frequently cited as examples of the danger that lay along the road of further import substitution.

These objections against increasing local content were held by many of the policy makers in the Secretary of Industry and Commerce. They were supported by most of the major terminal firms. ${ }^{22}$ The terminal firms, however,

${ }^{18}$ On the 1969 policy, see "Compensacion de Importaciones de Partes Automovilisticas," Comercio Exterior (1969): 864. For the 1972 Decree, see "Decreto que Fija las Bases para el Desarrollo de la Industria Automotriz," Diario Oficial (24 October 1972).

19 "Decreto Para el Fomento de la Industria Automotriz," Diario Oficial (20 June 1977): 2-7.

${ }^{20}$ A study done by Ford and submitted to the government showed that increasing the level of local content to 90 percent would raise prices 36 percent; Ford Motor Company, "Estudio Sobre Contenido Nacional y Generacion de Divisas por Exportaciones," mimeo, May 1976.

${ }^{21}$ The Ford study contended that the industry would have to invest $\$ 2.50$ for every $\$ 1.00$ of yearly savings in foreign exchange between 1980 and 1985 if increased local content were the option chosen, whereas if compensatory exports were chosen, that same yield in foreign exchange savings could be achieved with $\$ 0.60$ of investment.

${ }^{22}$ One major firm, Fábricas AutoMex, was not opposed to increasing local content. Prior to 1970 this firm was majority Mexican owned; the minority share was Chrysler's. In part, because of Chrysler's pricing policy to its majority Mexican owned subsidiary, Fabricas AutoMex had a difficult time competing with the 100 percent foreign owned subsidiaries of Ford and General Motors. In its efforts to improve its market position, Fábricas AutoMex proposed merging with the two other surviving Mexican owned firms (DINA and VAM). With government production 
were not anxious to be forced into required exports either: they preferred the freedom to follow "market forces" to any government regulatory schemes. The officials in Industry and Commerce under Diaz Ordaz, however, were not only more outward-looking than their predecessors, but were anxious to solve what they saw as an important element in the increasingly serious balance of payments problems. In 1969 and 1972 they did urge the compensatory exports route. Exports seemed attractive on a number of grounds. They promised to cure the balance of payments problem that the industry posed without raising prices. They even held out the hope of lowering prices: the industry would have to grow more efficient in order to compete successfully on the international market.

The initial hesitations about looking to exports for a solution lay in questions of feasibility rather than desirability: how could the unwilling transnationals be brought to export? When the United States and Canada signed an agreement in 1965 making the two countries a free-trade zone in automotive products, the Mexican government took particular interest. ${ }^{23}$ But a similar agreement between the United States and Mexico seemed impossible. The Canadian-U.S. agreement had required Senate ratification of a treaty. Lower wage rates in Mexico would surely make tougher going for a similar Mexican-U.S. treaty. The Canadian plan had won Senate approval only with the strong lobbying efforts of the U.S. automotive transnational firms, and these firms, having just been required to commence manufacturing in Mexico, were unlikely to favor exports from these plants competing with products from their U.S. plants. There were other problems. The newly-established Mexican industry, because of small-volumes and high raw material costs, was not yet price competitive, and there were persistent problems of quality.

Since it seemed unlikely that the automotive firms could be encouraged to export voluntarily (except perhaps via massive subsidies), some degree of compulsion would be needed (as it would as well were higher local content to be chosen). The sanction most readily available was the granting or withholding of production quotas to the terminal firms. These production quotas had been instituted with the first (import substituting) auto decree of 1962 with the express purpose of protecting the Mexican-owned (and thus presumably weaker) firms in the industry. ${ }^{24}$ Limiting production via quotas

quotas guaranteeing the new firm almost half of the market, and the economies of scale that would come through the merger, Fábricas AutoMex argued that increasing domestic content would be economically feasible and could be done with a minimal rise in consumer prices. The merger, however, fell through, in part because of opposition from the other companies. This intercorporation conflict, which enhanced the bargaining power of the Mexican government, will be discussed in a forthcoming paper.

${ }^{23}$ On this agreement, see Paul Wonnacott, "Canadian Automotive Protection: Content Provisions, the Bladen Plan, and Recent Tariff Changes," Canadian Journal of Economics and Political Society 31, 1 (February 1965): 98-115. On how the pact has fared since see, "Don't Shoot, They're Our Allies," Forbes (15 May 1973): 135-6; and Richard J. Fosdick, "U.S.-Canada Pact Re-examined," Automotive Industries (15 June 1975): 14-15.

${ }^{24}$ Actually there were quotas before 1962, but these served primarily to limit the total volume of automotive imports. 
would ensure these Mexican firms a market. But it was also recognized that the quotas afforded the government a more general tool of control over the terminal firms.

Under the terms of the 1962 Decree, the terminal firms were granted basic quotas, but the Decree also contained a clause which allowed that firms which exported finished vehicles, parts, or tooling could be awarded extra quotas. ${ }^{25}$ Over the next several years extra quotas were granted for exports as well as for other special considerations.

The 1969 Decree, however, stipulated that firms would no longer simply be granted their basic quotas. These would now have to be earned by compensating for a steadily increasing percentage of their imports, 5 percent in 1970, 15 percent in 1971, and so on. ${ }^{26}$ Exports beyond these levels would still earn extra quotas. This scheme was consolidated and extended in the 1972 Decree; by 1979, firms were to be compensating for 100 percent of their imports with exports. Access to the domestic market was thus to be used to force exports.

The compensatory exports did not have to be products of the terminal firms themselves; they had only to be automotive related products. ${ }^{27}$ Indeed, the legislation was designed to encourage the transnational terminal firms to arrange exports for Mexican parts suppliers. ${ }^{28}$ If the terminal firm arranged for the export of products from an automotive parts firm, the terminal firm would be credited for the export, for purposes of earning its basic quota.

For the first few years of the new requirements, the terminal firms succeeded in making or arranging the necessary exports. But in 1974 and again in 1975 the firms fell short of the mandatory levels. (See Figure 3.) Nevertheless, they were still granted their basic quotas, largely on the basis of promises to comply with export requirements in the future. How much the actual shortfall of exports was is a somewhat complex and contested matter which hinges on how the export obligations of the firms are computed. ${ }^{29}$ What was more

is This clause was included in the Decree because of the urging of Ford which had already developed a special kind of tooling for export to other Ford plants.

${ }^{26}$ How were the transnational firms in the terminal industry induced to accept this new scheme? That is an important and difficult question, one that concerns the balance of bargaining power between these transnational firms and the Mexican government. We mean to analyze the origins of this 1969 Decree in some detail in a later publication, but it suffices here to note that competitive maneuvering among the firms, particularly involving Fabricas AutoMex (Chrysler) and Ford in which each was trying to capture an enlarged share of the market, served to enhance the bargaining position of the Mexican government and make possible this important shift in policy.

${ }^{27}$ At first, even this was not clear. One high government official told us that several of the terminal firms explored the idea of exporting unrelated products-one even considered exporting potatoes-to compensate for their imports.

${ }^{28}$ Since the only part the terminal industry could produce (under the 1962 Decree) was the motor (and this was restricted to machining), the terminal firms would have to look to the Mexican parts industry if it wanted to export parts other than motors. In practice, however, many were able to integrate into the parts industry, the most fully integrated operation being that of Volkswagen.

${ }^{29}$ Under the terms of the 1972 Decree, the automobile firms were required to compensate a certain percentage of their import bill with exports, but they could also earn an 'extra-quota' of cars that could be sold in Mexico for exporting automotive products. During the years of the 
Figure 3: Export performance of the Mexican automobile industry

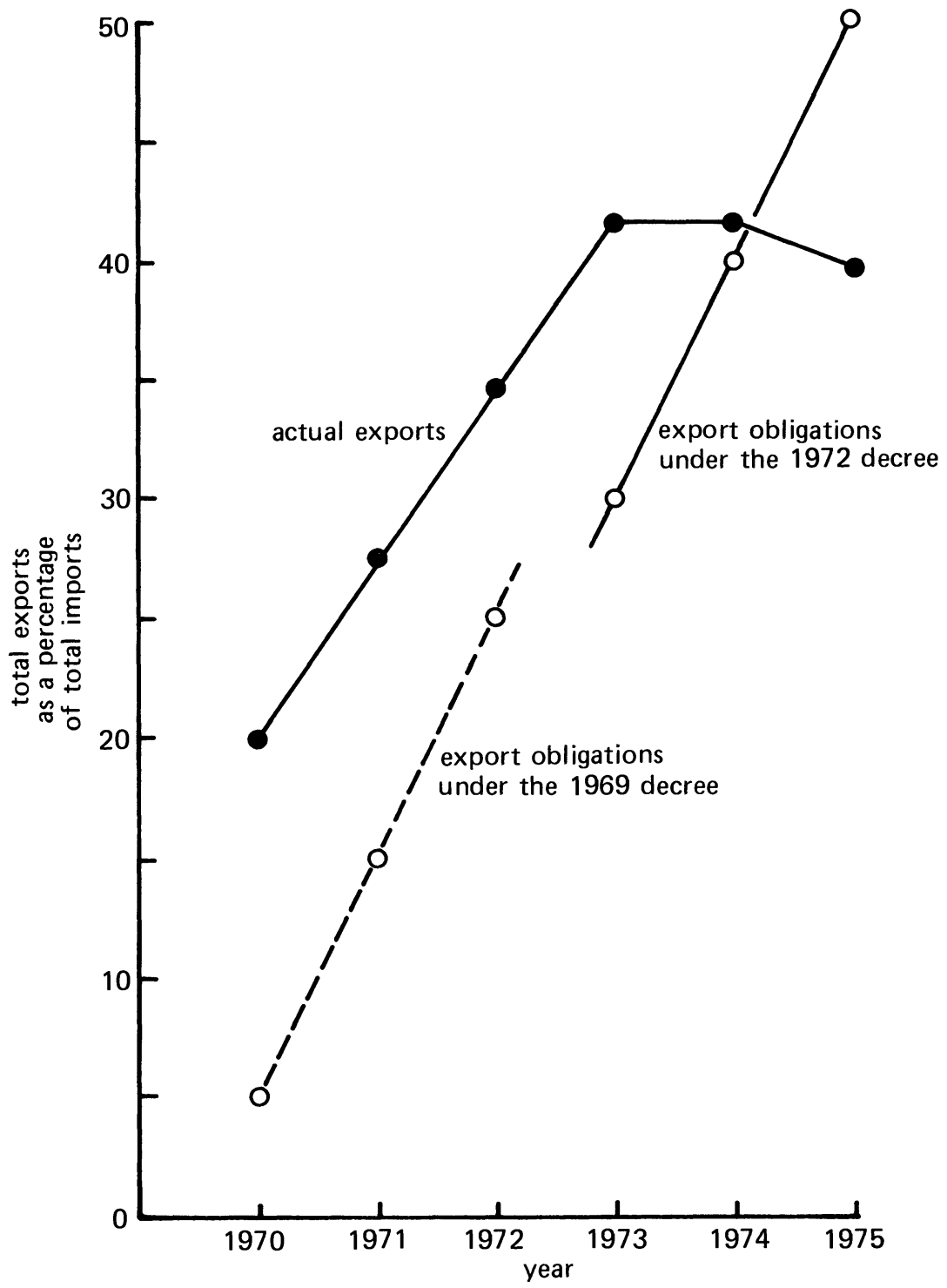

Source: Secretary of Industry and Commerce

shortfall, most of the automobile firms asked for and were granted an extra-quota on the basis of certain exports, even though these firms had not met the export obligations for their basic quotas. Clearly, the export shortfall is greater if one considers the total export obligation of the firms as including export commitments made to gain extra-quota than if one asks only if the total exports of the firms compensated for the required percentage of automotive imports (leaving these extra-quota commitments out of consideration). 
important than the precise shortfall in exports, however, was the meaning that the automobile firms and the government placed on this unhappy episode.

The automobile companies immediately looked to place the blame for the export shortfall on certain special factors, particularly on the worldwide recession in the automobile industry in 1974-75 and on the overvaluation of the Mexican peso. Once these difficulties cleared up, they argued, export compensation would proceed apace. The Echeverría administration took a different view. These officials noticed that despite the auto export program there continued to be a steadily growing absolute gap between the exports of the automobile industry and the imports of the terminal firms (see Figure 2), something that surely did not originate with the 1974-75 world auto market slump. And secondly, they were struck by the vulnerability of the auto export program to external conditions such as the 1974-75 world auto market slump.

With these considerations in mind, the Echeverría administration began to entertain serious reservations about continuing the export compensation program. Many of the officials in this government charged with making industrial policy had served previously in the López Mateos administration and continued to have an orientation towards an "inward-looking" industrialization strategy. In 1975-76 they drafted a new Decree governing the automobile industry that would have returned the basic policy orientation to import substitution. The Decree would have required considerably higher local content rather than compensatory exports as a way to spur industrial growth and cure balance of payments troubles in the industry. The last months of the Echeverría administration were beset by difficulties, however: a devaluation of the peso in September 1976 (the first in a quarter century), and a general crisis of confidence, in addition to the normal troubles of a lame-duck administration in Mexico. When the Lopez Portillo government took office in December 1976, it undertook a new study of the industry and a new formulation of policy. The orientation of this administration was much more "outward looking." Its Decree of 20 June 1977 required somewhat higher local content, but it once again committed the Mexican government and the automobile firms to compensatory exports as the dominant policy strategy in the industry.

The decision of the Lopez Portillo government to pursue an outward-looking strategy in the automobile industry kept the industry within the bounds of current development orthodoxy. But the previous decade's experience with export promotion in the Mexican automobile industry points to a number of difficulties with export promotion strategies which have been commonly overlooked in recent discussions recommending such strategies, difficulties that spring from the power exercised by a handful of transnational corporations in both the Mexican terminal industry and the world automobile industry. We will consider a) demand rigidities for export products introduced by TNC domination of the world automobile industry, b) some considerations of decision dependency that stem from the foreign ownership of the terminal 
firms, c) some difficulties in enforcing sanctions against TNCs under an export promotion policy, and d) the unequal distribution of benefit between foreign-owned and domestically-owned firms under such a policy.

\section{Transnational corporations and the political economy of export promotion}

\section{Demand rigidities: transnational corporations and export possibilities}

What contribution are transnational corporations making to increasing exports from developing countries? A number of studies have shown that subsidiaries of TNCs have in fact been responsible for a disproportionately large share of the manufacturing exports from developing countries. A study of José de la Torre, for example, showed that "U.S. Affiliates accounted for only 9.5 percent of Latin America's gross manufacturing value added, although their share of manufacturing exports was 41.4 percent." ${ }^{30} \mathrm{~A}$ recent study by Fajnzylber and Tarrago, however, reached rather different conclusions for Mexico. They showed that the share of transnational corporations in total manufacturing production is approximately equal to their share in total manufacturing exports-about one third. ${ }^{31}$

In making sense of various data about the contributions of TNCs to exports from developing countries, several points need to be kept firmly in mind:

First, without doubt, subsidiaries of transnational corporations are in an advantageous position with regard to exports. Potentially, they have access to market information, distributional channels, and international marketing skills that are not available to domestic firms. Clearly, they have the wherewithal, but have they the inclination? That is a largely separable consideration. In answering this we need to attend to the competitive contexts and corporate strategies of TNCs: what factors have led them to establish manufacturing subsidiaries in developing countries, and how do these subsidiaries fit into the firms' wider global strategies. If a subsidiary was established to take advantage of a readily available raw material or of cheap labor, then the parent firm may well be inclined to develop exports from the subsidiary; but if the subsidiary was established to serve the developing

\footnotetext{
${ }^{30}$ José de la Torre, "Foreign Investment and Export Dependency," Economic Development and Cultural Change 23 (1974-75): 138.

${ }^{31}$ Fernando W. Fajnzylber, and Trinidad Martinez Tarrago, "Las Empresas Transnacionales; Expansión a Nivil Mundial y Proyección en la Industria Mexicana," versión preliminar, mimeo, México 1975, p. 538. Their study also showed that TNCs were more likely than national firms to be substantial exporters-35 percent of TNCs but only 26 percent of national firms export more than $M \$ 500,000$ per year-but that export activities were largely "irrelevant" for the overwhelming majority of TNCs in Mexico. 72 percent of the TNCs in Mexico export less than 1 percent of their output, and 89 percent export less than 3 percent.
} 
country's domestic market, particularly if the TNC entry was a defensive move, such exports may not be welcomed by the parent firm at all.

Where the subsidiaries of transnational firms have the wherewithal to export but lack the inclination because of considerations of global corporate strategy, then such exports may be induced by government policies. Such inducements may not only require incentives to export (subsidies, tax advantages, etc.), but stronger forms of compulsion: where transnational corporations are involved, export promotion may need sticks as well as carrots. ${ }^{32}$

Second, a very high percentage of the exports from subsidiaries of transnational corporations are intracompany transfers. Where this is so, inducing a firm to export is really better understood as a matter of inducing its parent firm to buy. Comparative advantage theory would focus our attention almost exclusively on supply-side considerations: are the products for export of competitive price and quality? The central role of intracompany transfers shifts our attention towards demand-side considerations, the factors that bear on the willingness of parent firms to buy manufactured goods from their own subsidiaries-and these factors may well go beyond price and quality. The structure of the international automobile industry-its domination by eight or so transnational firms-exhibits some demand rigidities that surely are as important as the supply-side factors emphasized by the new orthodoxy of export promotion in determining whether exports of manufactured goods may be possible from developing countries.

Fully assembled vehicles constitute a steadily diminishing share of total world automotive trade as the transnational firms establish assembly or manufacturing plants abroad, often in response to government policies requiring domestic manufacture. In those markets where export sales of finished vehicles are still possible (for example in the smaller countries of Central America) transnational firms are most unlikely to allow their various subsidiaries to compete with one another or with the main plant in the home country. The decision as to which plant to permit to supply the market will depend on complex considerations based on the global rationality of the transnational firm-where the greatest opportunities for profit are to be found. This depends only in part on the costs of production of each subsidiary. Transportation costs and comparative tax burdens are also important, and the major automobile firms have sought to maintain production volumes

\footnotetext{
${ }^{32}$ It follows that if government policies have (and have had) a strong hand in influencing whether transnational corporations will export manufactured goods from developing countries, then it does not make sense to ask in a general sort of way what contribution transnational corporations make to increasing exports from developing countries. Asking the question in this manner ascribes responsibility solely to the TNCs. Instead, we need to ask to what extent can different kinds of government policies in different manufacturing sectors be effective in inducing TNCs to export. This would argue as well against a procedure such as Boatler's in which he tries to explain the unexpectedly high capital intensity of Mexico's manufactured exports, but begins by ruling out of consideration explanations that turn on government policy ("Trade Theory Predictions and the Growth of Mexico's Manufactured Exports,' Economic Development and Cultural Change 23 (1974-75): 492, note 3).
} 
Table 2: 1975 Mexican automotive exports

\begin{tabular}{lcccc}
\hline \hline & & \multicolumn{3}{c}{ Percentage of Exports Which Are } \\
\cline { 3 - 5 } Firm & $\begin{array}{c}\text { Total } \\
\text { Value of }\end{array}$ & $\begin{array}{c}\text { Assembled } \\
\text { Vehicles }\end{array}$ & $\begin{array}{c}\text { Parts Made } \\
\text { by Firm } \\
\text { Itself }\end{array}$ & $\begin{array}{c}\text { Parts Made } \\
\text { by Auto- } \\
\text { Parts Firms }\end{array}$ \\
\hline Chrysler & 708,401 & 3.6 & 75.8 & 20.6 \\
DINA (Renault) & 133,071 & 24.8 & 1.5 & 73.6 \\
Ford & 542,705 & 0.7 & 26.8 & 72.4 \\
G.M. & 344,649 & 0.0 & 45.9 & 54.1 \\
Nissan (Datsun) & 101,573 & 37.8 & 41.4 & 20.8 \\
VAMSA (A.M.C.) & 128,790 & 0.0 & 0.2 & 99.8 \\
Volkswagen & 617,691 & 11.5 & 88.5 & 0.0 \\
TOTAL & $2,576,880$ & 6.6 & 55.6 & 37.8 \\
\hline
\end{tabular}

${ }^{*}$ In 000 s of pesos.

Source: Secretary of Industry and Commerce

in their home country plants because of the high scale economies and substantial fixed-capital costs in these locations, and because of the importance of maintaining relationships with their regular parts suppliers. Exports of finished vehicles accounted for only 6.6 percent of Mexican automotive exports (see Table 2). It is noteworthy that the three firms that were the largest exporters of assembled vehicles from Mexico (Volkswagen, Nissan, and DINA-Renault) were those without major assembly plants in the United States and that a high proportion of these exports were destined for Central and South America. As more countries insist upon local manufacture or assembly of vehicles sold in the domestic market, government policy is likely to prove less efficacious in increasing exports of assembled vehicles. Export possibilities are more likely to be found in automotive parts-for original equipment or for replacement.

Some parts for new cars are produced by the automobile firms themselves (e.g. body stampings, motors), and others are regularly purchased from parts suppliers. Decisions by the automobile firms about where to produce their own parts (in which plant or subsidiary in the world) where not stipulated by government policy are based on calculations involving considerations of quality, reliability of supply, and cost of production. Since these sales of parts are intracompany transfers, however, pricing can be arranged to take advantage of tax schedules in different countries (availability of subsidies and credits for investment, for exports, etc.) or to accord with a variety of other considerations of global strategy. Since prices of export parts are open to a substantial degree of manipulation, simply being capable of manufacturing parts at competitive costs might not be sufficient to win Mexico a share of this kind of world trade.

Where parts are procured from independent suppliers, transfer pricing is less of a concern; but procurement decisions here are similarly conditioned by factors other than cost and quality. The major auto manufacturers have long-term relationships with many of their important parts suppliers which 
they are particularly eager to maintain, and which might lead them to be hesitant to accept imports from Mexican parts firms. ${ }^{33}$ There is a vicious circle to be noted here as well. For many parts, the size of the Mexican market means that a parts manufacturer cannot produce at a price that would be competitive for export, but it may only be through such exports that the costs can be reduced to competitive levels. The Mexican manufacturer, however, will not make the investments for enlarged, more efficient production without the assurance of the export market, particularly because for a great many of these parts-in view of the product differentiation in the industry-there is only one potential buyer. One can hardly speak of a world market.

Finally, there is the "after market"-replacement parts. This is a more open market than those for assembled vehicles or original equipment parts, but there are significant TNC-induced rigidities here as well. A large number of buyers are to be found in the after market-garages, repair shops, dealers, auto supply stores, etc. - in addition to the transnational auto firms. For some parts involving simple technology which have broad suitability across makes, models, and years such as wheel rims, windshields, shock absorbers and the like, competitive price and quality may be sufficient to capture a share of the market. But for parts which embody sophisticated technology or which must meet the product design specifications of a particular make or model, export sales will be possible only if the auto manufacturer (or its parts supplier) is willing to license the necessary technology or designs. For various reasons, such licenses may not be available. ${ }^{34}$

Although there may be more export opportunities in this third market, the general point still holds, that export possibilities are largely controlled by the transnational automobile firms (and their major parts suppliers) to fit the requirements of their global strategies. Promoting auto exports from Mexico would seem to require two kinds of action: action to lower the costs of parts that have export potential, and action to find ways to induce the transnational auto firms to buy the parts. It is important to bear in mind that achieving the first does not necessarily entail achieving the second. The Mexican government appreciated this point in 1969 when it first began actively to promote auto exports. It did not look to use subsidies or other fiscal incentives to achieve the goal-policies which would have attacked primarily the supply side of the problem. Instead, the policy selected was one that attacked the demand side,

\footnotetext{
${ }^{33}$ Of course many of the Mexican parts firms are subsidiaries of U.S. auto parts firms, having been brought into Mexico with the encouragement of the major auto firms when manufacturing operations commenced in the early 1960s. When this is the case, the auto firms may arrange with their parts suppliers to import parts from these suppliers' subsidiaries in Mexico. Here again, however, transfer pricing arrangements intrude; and procurement decisions are based on more than considerations of cost and quality.

${ }^{34}$ There are some examples in Mexico of export manufacture of such parts for the after market. A Monterrey firm makes replacement body stampings for Mercury Cougars for export to the United States, but only because it has been allowed to obtain the necessary stamping dies. Volkswagen de Mexico supplies replacement fender and hood stampings for its 'Beetle' to the U.S. after market, a decision that was rational within the firm's global operations with the phase out of that model in the United States. and with the stamping presses and dies close at hand in Mexico.
} 
inducing the transnational auto firms to buy automotive exports from Mexico by making their subsidiaries' continued participation in the Mexican market contingent on the success of such exports. If the exports were not forthcoming, production quotas for the domestic Mexican market would be cut. When the terminal firms did not fully comply with their export commitments in 1974 and 1975 , however, their production quotas were not cut. Why the commitments were not met, and why the production quotas were not cut are questions that lead to two further points, one concerning decision dependency-that automotive export decisions are made outside of Mexico in Detroit, Wolfsburg, Paris, and Tokyo-and the other concerning some difficulties in the use of sanctions.

\section{Decision dependency}

The TNC subsidiaries had agreed (with a green light from their respective parents) to arrange exports of automotive products. But if such exports were to continue year after year, the parent firm would have to agree to buy the exports in each new year. What had been convenient in 1969, however, might not be convenient, in view of other global considerations, a few years hence. Reliance on exports to solve the balance of payments problem made Mexico dependent on the decisions of powerful transnational corporations for whom Mexico was only one manufacturing operation among many. The alternative of increased local content would not have had this effect. By decreasing the autonomy of the subsidiary, such a strategy might even have increased the autonomy of the subsidiary and made it more susceptible to being steered in accordance with national policy planning goals. Within the export promotion route, the Mexican government would need very strong leverage in order to compel the parent firm to alter its strategy, to buy Mexican exports, when this ceased to accord with the requisites of global rationality. Did Mexico ever have sanctions powerful enough that it could affect the decisions in Detroit?

Before considering the possibilities of effective sanctions, a second way in which the export promotion route increased Mexico's dependency on foreign decision centers should be examined. If exports were to be possible, Mexico would have to manufacture parts that conformed to the requirements of cars made elsewhere in the world; they would have to fit the models and makes produced for the major automobile markets. Consequently, a series of policies for rationalizing production within Mexico would become difficult or impossible to implement-policies such as the use of standardized parts or the mandatory freezing of model years. The policies designed to make car production more suitable for the conditions of the Mexican market might make Mexican automotive parts unsuitable for export. Decisions about product design, then, would necessarily be made outside Mexico, in answer to market conditions different from those within Mexico.

It is worth adding that the market structure resulting from export promotion would also increase the leverage of the TNCs in bargaining with the 
government over such issues as the percentage of local content (the TNCs could argue that increases might force price rises and "prevent" them from exporting) and vertical integration (the TNCs could insist on being allowed more vertical integration-at the cost of the Mexican supplier industry-on the argument that only they could meet the requisites of cost, quality, and delivery needed for export).

\section{Enforcement difficulties}

The sanction of reducing production quotas for failing to comply with export requirements may have been a powerful enough weapon to induce compliance, had the government been willing to use it, but it was a sword whose sharpness cut both ways, and which thus could not be unsheathed-for fear of injuring the country more seriously than the firms. If production quotas were decreased, the terminal firms would no doubt be hurt in several ways. Sales would decrease. Unit costs of production would increase, given the scale economies, thus cutting the profit margin on the units that could be sold under the smaller quota. Sales of parts from the parent to the subsidiary would decrease, thus decreasing earnings for the parent obtained through such sales. But the harm to the country would be yet more varied. Decreased production would mean fewer jobs in the terminal firms for Mexican workers. Fewer parts would be bought from the supplier firms; their sales would decrease, their profits as well, and more workers would be laid off. Automobile manufacture was desired in Mexico because of the manifold consequences it would have in stimulating other industries. Should quotas be decreased, those backward and forward linkages would transmit production cutbacks in terminal firms throughout the industrial structure of Mexico. ${ }^{35}$

Sanctions of another sort might be possible-monetary fines or tax penalties, for example-that would not be so sharply double-edged, which would penalize the earnings of the terminal firms without leading to a decrease in their levels of production. It is worth pointing out that enforcement difficulties would not be so severe with a requirement of increased local content. There would be less dependence on decisions taken outside of Mexico, and import permits would be used to insure that the required level of local content was being incorporated by each terminal firm. Production sanctions would be unnecessary.

${ }^{35}$ The sanction of quota reductions could be used if only one or two of the terminal firms failed to meet their export commitments. The quotas of the other firms could be correspondingly increased and aggregate levels of production, employment, parts purchases, etc. would be maintained. Given the character of the world automobile industry, it is likely that a short-fall in exports by one firm would be matched by all, as occurred in Mexico in 1974-75 (unless one of the smaller firms in the world industry-American Motors, for example-began to lose its competitive viability). And it is also important to note that while aggregate production might be maintained, there would be distributional consequences, and not just for the terminal firm involved (i.e. for workers, parts suppliers, etc.) See the next section. 
One other enforcement consideration concerns the possibility of counter-measures from the developed countries. A policy that requires the TNCs to import into their home countries is surely more likely to provoke protectionist reprisals from the home country governments of the TNCs than a policy that requires these firms to export less from their home countries. ${ }^{36}$

\section{The distribution of benefits}

One last drawback of a policy requiring exports as opposed to requiring increased local content warrants mention. If one is only considering the aggregate effects of the two alternatives-the total effect on the balance of payments or on the gross domestic product, for example, requiring exports is not a drawback. But suppose we inquire not of the aggregate effects but of the distribution of benefits: who benefits from requiring exports and who from requiring increased local content?

A policy of requiring exports has worked to the disadvantage of the terminal firms which are not wholly foreign-owned subsidiaries of transnational firms. We have argued that inducing the terminal firms to export means inducing their transnational parents to buy. But where a terminal firm is linked to a transnational auto firm only through a license or a minority equity holding, this is difficult. The sanctions available to the Mexican government (granting or withholding production quotas for the Mexican market) are much less efficacious. Consequently, the two firms that are majority Mexican owned, DINA and VAMSA, have the poorest export records. The government can at its discretion overlook these poor export records and has, but only at the cost of making these firms appear to need continued government favoritism to stay in business. ${ }^{37}$ In addition, the imposition of the export requirements in 1969 was the proximate cause of the denationalization of the Chrysler subsidiary. Before that year, the majority of Fábricas AutoMex (as the firm was then called) was owned by the Azcárraga family. When the export requirements were introduced, however, Chrysler was not willing to commit itself to purchases of such exports from Mexico unless it directly controlled the subsidiary. In 1970 Chrysler purchased nearly all of the Mexican-held stock. While the export requirements were not the sole determinant, they were a major contributing factor.

When we turn our attention from the terminal firms to the parts supplier firms, equally striking distributional consequences are to be noted. A very few

${ }^{36}$ Fred Bergsten has suggested that any such 'performance requirements' placed by LDCs on TNCs may provoke such reprisals. "Coming Investment Wars?" Foreign Affairs (October 1974): 135-52. While the economic consequences may be roughly equivalent-lost jobs, etc. - the greater visibility of a policy that requires the home country to accept imports of products it once made for itself would make more likely the political reaction that could provoke the counter-measures.

${ }^{37}$ Moreover, the diadvantaging of these firms through export requirements decreases the possibility of using these two government-owned firms as instruments to regulate the wholly foreign owned firms. 
Table 3: 1975 exports from automotive parts firms

\begin{tabular}{|c|c|c|c|}
\hline Firm & $\begin{array}{c}\text { Foreign Participation } \\
\text { in Equity }\end{array}$ & $\begin{array}{c}\text { Total } 1975 \\
\text { Exports (in } \\
\text { Mexican Pesos) }\end{array}$ & $\begin{array}{c}\text { Percentage of } \\
\text { Total Exports } \\
\text { from Auto } \\
\text { Parts Firms }\end{array}$ \\
\hline $\begin{array}{l}\text { 1. Transmisiones y Equipos } \\
\text { Mecanicos (TREMEC) }\end{array}$ & $\begin{array}{l}\text { (Clark Equipment Co.) } \\
\text { Yes (34 Percent) }\end{array}$ & $405,934,529$ & 41.7 \\
\hline $\begin{array}{l}\text { 2. Equipo Automotriz } \\
\text { Americana }\end{array}$ & Yes (?) & $149,079,048$ & 15.3 \\
\hline 3. Rassini Rheem & $\begin{array}{l}\text { (Rheem International) } \\
\text { Yes (40 Percent) }\end{array}$ & $127,984,629$ & 13.2 \\
\hline 4. Whitaker & $\begin{array}{c}\text { (Whitaker Inter-America) } \\
\text { Yes (?) }\end{array}$ & $25,296,050$ & 2.6 \\
\hline 5. Aralmex & Yes (?) & $24,911,289$ & 2.6 \\
\hline 6. Industria Automotriz & No & $21,948,193$ & 2.3 \\
\hline $\begin{array}{l}\text { 7. Manufacturas Metalica } \\
\text { Monterrey }\end{array}$ & $\begin{array}{l}\text { (A. O. Smith) } \\
\text { Yes (40 Percent) }\end{array}$ & $20,744,295$ & 2.1 \\
\hline 8. F.U.M.E. & $(?)$ & $18,037,490$ & 1.9 \\
\hline 9. Automanufacturas & $\begin{array}{l}\text { (Budd Corp.) } \\
\text { Yes (?) }\end{array}$ & $16,093,927$ & 1.7 \\
\hline 10. Mex-Par Blackstone & $\begin{array}{l}\text { (Blackstone) } \\
\text { Yes (?) }\end{array}$ & $10,917,522$ & 1.1 \\
\hline $\begin{array}{l}\text { Total of Top Ten Exporting } \\
\text { Auto Parts Firms }\end{array}$ & & $820,946,972$ & 84.4 \\
\hline $\begin{array}{l}\text { Total Exports from All } \\
\text { Auto Parts Firms }\end{array}$ & & $973,142,915$ & 100 \\
\hline
\end{tabular}

Source: Secretary of Industry and Commerce

parts firms now account for the large majority of auto parts exports from Mexico. In 1975, forty (of several hundred) ${ }^{38}$ auto parts firms had some exports but one firm accounted for 42 percent of these, and ten firms accounted for over 80 percent (see Table 3 ).

It is likely that a determined policy of export promotion would generate additional sales for only these and a very few others. The majority of parts firms would not benefit.

An additional dose of import substitution-increasing the level of local content-would tend towards an opposite pattern of benefit. A few firms would be unaffected-those that are already supplying as many of the terminal firms as is possible. But new sales would be generated for a large number of firms who manufacture more or less standardized parts that are bought by only one or two of the terminal firms. At an increased level of required local content, other terminal firms would leave off importing these parts in favor of purchasing domestically manufactured items.

${ }^{38}$ According to Business Trends, a Mexican business annual, the auxiliary industry in 1975 consisted of " 560 plants (about 280 of which produce only automotive industry equipment)", Business Trends (1975): 215. 
A second point: the parts firms that succeed in exporting are disproportionately those with strong foreign equity participation. ${ }^{39}$ Thus, requiring exports tends to work against the goal of promoting Mexican investment. Data on ownership are difficult to obtain in Mexico, but at least six and probably eight or nine of the ten top auto parts exporting firms have strong foreign equity participation, and surely only a small percentage of the several hundred auto parts firms in Mexico have any degree of foreign ownership. According to one study, only 39 of 410 firms in the auto parts industry were subsidiaries of TNCs. ${ }^{40}$ One reason for the exporting success of the firms with foreign equity is the technical sophistication of these joint ventures-their products are more competitive in terms of price and quality. There is another and equally strong reason, however: the international automobile firms, having long-standing relationships with major parts manufacturers, prefer to buy from the subsidiaries of these parts manufacturers rather than from independent Mexican firms.

A third point is related. If exports are required, and if these exports are to be predominately auto parts rather than finished vehicles, then the terminal firms are sure to argue that extant restrictions on vertical integration should be lifted to allow the terminal firms to manufacture the parts that are to be exported, on the argument that only their control over the manufacture of these parts can ensure the necessary high quality, competitive cost, and timely delivery. To a small degree these arguments have already succeeded. Chrysler is now manufacturing and exporting condensers for air conditioners, and Ford is constructing a plant to manufacture hubs and drums, largely for export. Even if the restrictions on vertical integration remain, however, the terminal firms can themselves manufacture for export those parts which they are already permitted to manufacture (motors, for example). In such ways, export promotion will have worked against the goal of promoting Mexican investment.

\section{Conclusions}

Export promotion and import substitution are often characterized as exclusive alternatives, ${ }^{41}$ but they need not be so viewed. Once we recognize that import substitution laid the foundation for an industry that could become a

\footnotetext{
${ }^{39}$ By law, all auto parts firms must be at least majority Mexican owned (wholly foreign-owned subsidiaries are not allowed).

${ }^{40}$ Fernando Fajnzylber and Trinidad Martinez Tarrago, "Las Empresas Transnacionales: Expansión a Nivel Mundial y Proyección en la Industria Mexicana."

${ }^{41}$ See, for example, Little, Scitovsky, and Scott, p. 11. Product cycle theory as developed by Raymond Vernon and his associates, of course, depicts these as integrated parts of the same process. See, for example, Raymond Vernon, Sovereignty at Bay: The Multinational Spread of U.S. Enterprises (New York: Basic Books, 1971); and Louis T. Wells, Jr., ed., The Product Life Cycle and International Trade (Boston: Harvard University, Division of Research, Graduate School of Business Administration, 1972).
} 
candidate for export promotion, another possibility emerges: ways might be found by which further doses of import substitution might facilitate a greater volume of manufactured exports, while lessening the necessity of depending upon these exports. So long as the Mexican automobile industry was merely a CKD operation, assembling automobiles from imported kits, no exports were possible. Local content requirements created the manufacturing basis of the current industry. Motors, transmissions, springs, wheels and hubs-nearly all the principal automotive parts exports-first came to be manufactured in Mexico in significant volumes as a result of import substitution policies. ${ }^{42}$ Are there particular areas in which still further import substitution might actually encourage exports?

It is usually argued that there are not: a requirement of increased local content would raise automobile prices and thus make exports still more difficult. While it is likely to be the case that the price of assembled automobiles would increase, there is no reason to suppose that the prices of component parts already being manufactured would increase-and these will continue to constitute the bulk of auto industry exports. Further, a study made by one of the principal associations of automotive parts manufacturers showed that there were many parts which some terminal firms were procuring in Mexico but which other terminal firms were continuing to import. ${ }^{43}$ Higher local content requirements could compel all the terminal firms to procure these parts domestically, at no substantial increase in price; and the resulting greater domestic volume of production might well lower prices on these parts, perhaps even to the point of making their export more feasible.

As a general development strategy, import substitution industrialization proved to engender certain recurring and fundamental problems, principally the creation of an inefficient industrial structure and chronic balance of payments difficulties. In the wake of this experience, export promotion came to be championed as an alternative development strategy that could cure these troubles. The argument here, however, had been that, when employed in sectors dominated by subsidiaries of transnational corporations, an export promotion strategy may run afoul of difficulties of its own. These problems are not immediately apparent from the neo-classical, comparative-advantage perspective that has provided its principal theoretical support.

Where a manufacturing sector has been created through import substitution, the question is not so much whether or not to promote exports, but

${ }^{42}$ There are, of course, exceptions. Some auto parts manufacturing has been initiated primarily for export. Chrysler, for example, has begun manufacturing condensers for automobile air-conditioners for export. This kind of manufacture-for-export is almost strictly confined, however, to the parts manufactured by the terminal firms themselves. The general point holds for the supplier firms.

${ }^{43}$ The study was one submitted to the Ministry of Patrimony and Industrial Promotion in March 1977 by the Auto Parts section of the National Chamber of Manufacturing Industries. The organization's estimate was that the terminal firms could increase their purchases from auto parts firms (substituting for imports) by 27 percent without any new investments by the auto parts firms, and by an additional 21 percent with minimal new investments. 
whether or not to switch horses in midstream. If a particular industrial structure has been created under the influence of government policy and is dominated by transnational corporations following their global strategies (i.e. governed by considerations that transcend local conditions and government policy), then is the promotion of exports a possible and desirable policy? Such has been the question in the Mexican automobile industry. Given the ownership and structural characteristics of the international and Mexican automobile industry, the Mexican government's attempt to shift to export promotion in 1969 has brought certain difficult problems. The experience has shown that such a policy may be difficult to carry through a) because of demand rigidities for products in which there are substantial intracompany transfers, b) because of the decision dependency that is introduced by having to rely on decisions made in the TNCs' home countries, and c) because of certain difficulties in enforcing such a policy should it encounter recalcitrance. Such a policy may also be undesirable, even if it can be carried through, because of the resultant decision dependency and because of d) the unequal distribution of benefits it may produce between foreign-owned and domestically-owned firms.

Consideration of the desirability of export promotion policies must move beyond a general analysis of exchange rates, tariffs, and tax policies, and attend to the structure, history, and dynamics of specific candidate manufacturing sectors, both in the country in question and internationally. 